\title{
Continuïteit en verandering
}

\section{Voorwoord bij deze speciale editie van Tijdschrift voor \\ Arbeidsvraagstukken bij het emeritaat van redactievoorzitter}

Jacques van Hoof

\author{
Kees Vos en Roel Schouteten*
}

Dit is een unieke uitgave van het Tijdschrift voor Arbeidsvraagstukken. Uniek omdat het gaat om een hommage aan Jacques van Hoof. De directe aanleiding om een speciaal nummer aan hem te wijden vormt zijn afscheid als hoogleraar 'Arbeidsmanagement en omgeving' aan de Radboud Universiteit op 27 april 2007. De uiteindelijke aanleiding is gelegen in de geschiedenis van het tijdschrift. Nu 23 jaar geleden, in 1984 om precies te zijn, signaleerden Belgische en Nederlandse onderzoekers een gat in de markt. Klaarblijkelijk bestond er op dat moment behoefte aan een forum voor onderzoekers op het brede terrein van de arbeidsvraagstukken. Het resultaat was dat eind maart 1985 het eerste nummer van het Tijdschrift voor Arbeidsvraagstukken kon verschijnen. Sindsdien zijn er zonder onderbreking jaarlijks vier kloeke afleveringen verschenen, waardoor intussen een $23^{\mathrm{e}}$ jaargang is bereikt. Met Jacques van Hoof toen en nu als voorzitter van de redactie. Een betere symboliek van continuïteit en lotsverbondenheid is nauwelijks denkbaar.

Er is meer aan continuïteit. In het voorwoord bij het eerste nummer wees Jacques op "veranderingen die hun uitwerking op het denken over arbeid en de plaats van arbeid niet zullen missen. Technologische vernieuwingen binnen de arbeidsorganisatie, segmenteringtendenties op de arbeidsmarkt, verschuivingen in de relatie tussen werkgevers en werknemers (de arbeidsverhoudingen), de opkomst van 'onbeloonde' en 'informele' arbeid zullen de verhoudingen binnen en buiten het arbeidsbestel ingrijpend beïnvloeden". Anno
2007 oogt deze kenschets nog verrassend actueel. Weliswaar zijn de antwoorden anders en de accenten verlegd, maar de vraagstukken zijn vrijwel dezelfde gebleven.

Ongetwijfeld heeft de continuïteit in actualiteitswaarde bijgedragen tot de langjarige redactionele betrokkenheid van Jacques. Evenals trouwens zijn betrokkenheid bij de problematiek van de aansluiting tussen onderwijs en arbeidsmarkt, door de jaren heen zijn "core business". Daarbij gaat het Jacques niet, of beter: niet uitsluitend, om de arbeidsmarkt als concrete beleidsproblematiek. Zoals hij in zijn dissertatie "De Arbeidsmarkt als Arena" (1987) heeft aangegeven is het hem vooral begonnen om de brede maatschappelijke betekenis van de arbeidsmarkt, de arbeidsmarkt als maatschappelijk verdelingsmechanisme, een geheel van machts- en afhankelijkheidsrelaties. Met dit arena-perspectief heeft Jacques zichzelf willens en wetens tot veelzijdigheid veroordeeld. De diversiteit van de in deze bundel opgenomen bijdragen maakt dit nog eens extra duidelijk. Deze speciale editie bevat in chronologische volgorde de artikelen en (redactionele) bijdragen die hij in de loop der jaren in het Tijdschrift voor Arbeidsvraagstukken heeft gepubliceerd.

In Jacques' artikelen is deze veelzijdigheid duidelijk herkenbaar. Het eerste artikel van zijn hand is de bijdrage onder de titel "Interfaces en tussenschakels" in het tweede nummer van 1986. De conclusie hierin is dat buitenschoolse opleidingsvoor-

\footnotetext{
* Kees Vos en Roel Schouteten zijn beiden lid van de redactie van het Tijdschrift voor Arbeidsvraagstukken.
} 
zieningen onderwijs en arbeidsmarkt beter op elkaar kunnen afstemmen dan prognoses over toekomstige behoeften aan personeel. In zijn tweede bijdrage, in het derde nummer van 1991, gaat hij in op de veranderende rol van het personeelsbeleid. Hierin koppelt hij brede maatschappelijke ontwikkelingen en wetenschappelijke inzichten over de rol van personeelsmanagement aan elkaar, en schetst hij de uitdagingen voor het personeelsmanagement in de komende jaren. Hoewel in 1991 gepubliceerd heeft ook de conclusie van deze bijdrage nog nauwelijks aan actualiteitswaarde ingeboet.

Een derde artikel, getiteld "Arbeid, klasse en sociale gelijkheid", verschijnt in het eerste nummer van de tiende jaargang. Hier is de conclusie dat het klassebegrip ook in een postmodern tijdperk nog relevant is. Ter gelegenheid van het tienjarig bestaan van het tijdschrift verscheen kort daarna een congresbundel. Jacques' bijdrage hierin, getiteld "Arbeidsbestel op een keerpunt" (1995; niet opgenomen in deze speciale editie) schetst zijn observatie dat instituties in ons land altijd een pacificerende functie hebben gehad, waaraan wij de arbeidsrust en hoge arbeidsproductiviteit mede te danken hebben: "Wat dat betreft is het geloof in de onzichtbare, weldoende hand van de markt nu even misplaatst als een eeuw geleden".

Tenslotte is in deze speciale editie een artikel uit 1998 opgenomen die tien jaar institutionele vernieuwingen in de relaties tussen beroepsonderwijs en arbeidsmarkt behandelt.

Naast de artikelen bevat deze bundel ook een groot aantal andere bijdragen. In de achterliggende jaren heeft Jacques, alleen of samen met andere redactieleden of "externe" auteurs, themanummers en themakaternen geredigeerd over uiteenlopende onderwerpen, als Europa, vakbondsparticipatie, of vergrijzing. Voor een groot aantal afleveringen heeft hij de inleidende column verzorgd, waarin nu eens werd ingegaan op koersveranderingen in het redactionele beleid, dan weer op thema's die op dat moment actueel waren. In de bijdragen over actuele onderwerpen blijkt Jacques' vermogen om die ontwikkelingen in een breder perspectief te plaatsen. En ook in retrospectief blijken zijn analyses en obeservaties zeer accuraat en vaak ook nu nog actueel.
Daarnaast zijn bijzonder vermeldenswaard de artikelen die hij de laatste jaren heeft geschreven ter inleiding van themanummers en themakaternen: in 2003 het themakatern "Combineren en balanceren" (samen met Tanja van der Lippe), in 2004 het themanummer "Tijdconcurrentie" (samen met Tanja van der Lippe en Arie Glebbeek) en in 2006 het themakatern "De vergrijzende arbeidsmarkt" (samen met Paul de Beer).

De nadruk tot dusverre op continuïteit doet geen recht aan de grote veranderingen die in de afgelopen decennia eveneens hebben plaatsgevonden. Dit betreft niet alleen de wijzigingen in de vormgeving of het redactionele beleid. Op deze punten is Jacques overigens een onvermoeibare motor geweest bij de voortdurende zoektocht naar mogelijke verbeteringen van de "uitwendige" en "inwendige" kwaliteit. De veranderingen betreffen niet in de laatste plaats ook Jacques persoonlijk. In dit opzicht laat het colofon van de opeenvolgende jaargangen zich lezen als een langgerekt curriculum. Bij de start in 1985 staat hij nog genoteerd als doctorandus en werkzaam bij SISWO. Tussen het tweede en derde nummer van de derde jaargang vindt zijn promotie plaats en volgt de benoeming tot hoogleraar aan de Open Universiteit. Het derde nummer van 1992 vermeldt een dubbel professoraat: naast de OU ook de Universiteit van Leiden. In de $19^{\mathrm{e}}$ jaargang is de OU inmiddels verdwenen, maar wordt de Universiteit van Nijmegen toegevoegd. $\mathrm{Na}$ het emeritaat in Leiden in $2004 \mathrm{zal}$ dan in de thans lopende $23^{\mathrm{e}}$ jaargang opnieuw een aanpassing van het colofon moeten plaatsvinden. De redactie heeft gemeend hieraan op een gepaste en passende wijze aandacht te moeten besteden en wel door de uitgave van deze zeer speciale aflevering van het Tijdschrift voor Arbeidsvraagstukken. Immers, hoe kan de veelzijdigheid en eruditie van Jacques beter geïllustreerd worden dan door hemzelf aan het woord te laten? De redactie is degenen die aan de totstandkoming van deze speciale editie hebben meegewerkt bijzonder erkentelijk. De dank geldt de uitgever Elsevier Overheid voor de productie. De dank geldt voorts TNO Kwaliteit van Leven I Arbeid en het Nederlands Participatie Instituut/ Stichting Werkgemeenschappen Bergeyk voor hun 
financiële bijdrage, waardoor deze uitgave mogelijk is gemaakt. De dank geldt last but not least de auteur van de bijdragen aan deze editie. Want daar was het per slot van rekening om begonnen!

\section{Literatuur}

Hoof, J.J. van (1987). De arbeidsmarkt als arena. Arbeidsmarktproblemen in sociologisch perspectief. Nijmegen: SUA.

Hoof, J.J. van (1995). Arbeidsbestel op een keerpunt. Tien jaar veranderingen in arbeidsorganisatie, arbeidsmarkt en arbeidsverhoudingen vanuit een langetermijnperspectief. In L. Faase, M. Ott, C.J. Vos (red.). Nieuwe breukvlakken in het arbeidsbestel? Balans van 10 jaar veranderingen in Nederland en België. Utrecht: De Tijdstroom. 